\title{
General public Knowledge of coronavirus disease 2019 (COVID-19) at early stages of the pandemic: results of a random online survey in the Kingdom of Saudi Arabia
}

\author{
Ali Alqahtani \\ King Khalid University \\ V Krishnaraju \\ King Khalid University \\ Mona Alqarni \\ Medical Services Company by AbbVie Biopharmaceutical \\ Mohammed Al-Sheikh Hassan ( $D$ P17236771@my365.dmu.ac.uk) \\ De Montfort University
}

\section{Research Article}

Keywords: Coronavirus, COVID-19, Knowledge, Prevention, Quarantine, Pandemic, Saudi Arabia

Posted Date: August 6th, 2020

DOl: https://doi.org/10.21203/rs.3.rs-54864/v1

License: (c) (i) This work is licensed under a Creative Commons Attribution 4.0 International License. Read Full License

Version of Record: A version of this preprint was published at Patient Preference and Adherence on August 6th, 2020. See the published version at https://doi.org/10.2147/PPA.S300641. 


\section{Abstract}

\section{Abstract}

Background: A novel coronavirus was identified at the end of 2019 in Wuhan City, China. Later, the World Health Organization (WHO) named the disease caused by the virus coronavirus disease 2019 (COVID-19) and declared a pandemic in March 2020. Saudi and global health agencies have provided various COVID19 knowledge tools and facts to the general public. Therefore, this study aims to assess COVID-19 knowledge among the general public in Saudi Arabia at the early stages of the pandemic, including knowledge of prevention practices, home quarantine measures, and compliance with governmental restrictions.

Subjects and methods: A cross-sectional study was conducted in March 2020 during the COVID-19 pandemic in Saudi Arabia. The study included 1006 participants who responded to a random online COVID-19 public knowledge questionnaire that included five sections: demographic characteristics, general knowledge, prevention practices, home quarantine measures, and knowledge of governmental restrictions. Data were collected from a random sample recruited through the circulation of the questionnaire on social media platforms and were then analysed by descriptive statistical methods. Three levels of knowledge were established: excellent, intermediate, and poor. Differences in the percentages of participants with different knowledge levels by the demographic variables were analysed using the chi-square test.

Results: Regarding overall general knowledge of COVID-19, 75\%, $24 \%$, and $1 \%$ of the participants had excellent, intermediate, and poor knowledge levels, respectively. Knowledge levels were significantly different by nationality and age ( $P=0.027$ and 0.008 , respectively). The majority of participants $(98.4 \%)$ reported excellent knowledge of prevention practices, with no statistically significant differences among groups $(P>0.005)$. Older age groups reported higher knowledge of home quarantine measures $(86.6 \%$ and $86.4 \%$ of the $51-60$ and older than 60 age groups, respectively, $P=0.001$ ). Approximately $50 \%$ of Saudis reported excellent knowledge of the restrictions imposed by the Saudi government to control the spread of COVID-19, while approximately $45 \%$ of non-Saudis had an excellent level of knowledge $(P=0.009)$.

Conclusion and recommendations: High levels of knowledge about the virus, including prevention practices, are essential. The provision of COVID-19 facts and knowledge tools should be focused on younger generations to enhance compliance with the governmental restrictions required to stop the spread of COVID-19.

\section{Introduction}

To date, six different coronaviruses (CoVs) [OC43 [1, 2], 229E [1, 2], NL63 [3, 4], HKU1 [3, 4], severe acute respiratory syndrome coronavirus (SARS-CoV) $[5,6]$ and Middle East respiratory syndrome coronavirus (MERS-CoV) $[5,6]]$ have been identified in humans. Of these six CoVs, the first four were endemic, and the 
last two were epidemic. In general, endemic CoVs produce mild infections [7] and does not harm humans to a greater extent.

However, the two epidemic CoVs that have emerged in humans in the last 2 decades, SARS- CoV in 2003 and MERS-CoV in 2012, had devastating consequences. Notably, both epidemic CoVs belonged to beta CoV subgroups, and the outbreaks resulted in high case fatality rates. SARS-CoV affected at least 8000 individuals with a case fatality rate of approximately $10 \%$ [8], whereas MERS-CoV affected more than 2000 people, and the case fatality rate was approximately $35 \%$ [9].

Recently, a more virulent CoV was identified at the end of 2019 in Wuhan, a city in Hubei Province of China [7]. The virus was temporarily named 2019 novel coronavirus (2019-nCoV) by the World Health Organization (WHO) [10]. On February 11, 2020, the WHO named the virus severe acute respiratory syndrome coronavirus 2 (SARS-CoV-2) and the disease caused by the virus coronavirus disease 2019 (COVID-19) [11]. In a short period, SARS-CoV-2 spread rapidly and resulted in an epidemic throughout China, followed by an increasing number of cases in other countries throughout the world. Based on this global spread of SARS-CoV-2, a pandemic was declared by the WHO on March 11, 2020 [12].

SARS-CoV-2 can be transmitted by both symptomatic [13] and asymptomatic individuals [14]. Although the extent of infection is unknown among asymptomatic individuals, it is reported to be from $0.45 \%$ to $5 \%$ among symptomatic individuals. SARS- CoV-2 is reported to have an incubation period of 14 days [15, 16], with a median incubation period of 4 days [16] to 5.1 days [17]. The severity of COVID-19 symptomatic infection ranges from mild to critical. Most infections are not severe [16]. The severity depends predominantly on advanced age or underlying medical comorbidities. Various clinical studies have reported COVID-19 case fatality rates from 0.7 to $7.2 \%[13,18,19]$ with notably increased mortality rates associated with older age. Among the clinical manifestations, pneumonia appears to be the most frequent, primarily accompanied by fever, fatigue, dry cough, anorexia, myalgias, dyspnoea, and bilateral infiltrates on chest imaging $[7,20,21]$.

Saudi Arabia reported the first case of COVID-19 on March 2nd, 2020, for a person who arrived from Iran through the Kingdom of Bahrain [22]. Consequently, newly recorded cases of COVID-19 continued to increase, and the first reported death in Saudi Arabia was recorded on March 24th, 2020 [23]. Due to the rapid spread of COVID-19 across countries and the increasing number of reported cases and deaths, the Saudi government imposed extreme restrictions to control the spread of COVID-19, which included closing schools and universities, banning domestic and international travel, and temporarily suspending group prayers at mosques, including Umrah at the holy mosque in Makkah. Moreover, local and global health agencies started to provide various COVID-19 knowledge tools and information for the general public. Therefore, this study aimed to assess COVID-19 knowledge among the general public in Saudi Arabia, including knowledge of prevention practices, home quarantine measures, and compliance with governmental restrictions. 


\section{Methods}

\section{Participants and methods}

\section{Study design}

A cross-sectional study was conducted in March 2020 during the early stages of the COVID-19 pandemic. Data were collected using Google Forms, through which an online questionnaire was randomly circulated on social media platforms such as Twitter, Facebook, and WhatsApp in the Kingdom of Saudi Arabia with no consideration as to the geographic location of participants. The study collected responses from the general public regardless of their demographic characteristics or their degree of risk for acquiring COVID19. Responses were collected for one week until no more responses were received. Raosoft [24] sample calculation software recommended a minimum of 385 subjects using the total Saudi population size of people aged 15 years or older of $25,828,206$ [25], response distribution of $50 \%$, confidence interval of $95 \%$, and margin of error of $5 \%$. A total of 1363 responses were received, including responses from 357 healthcare workers, which were excluded from this study. The final sample consisted of 1006 random responses from the Kingdom of Saudi Arabia. The study included subjects of both genders who were at least 15 years old. Ethical approval was obtained by the research ethics committee at King Khaled University in Abha, Saudi Arabia. Participants were asked to take part in the study voluntarily and to not provide personal or identity-revealing information.

\section{Study tools}

Data were collected using a questionnaire that was designed based on the latest general public information on COVID-19 published by the Centers for Disease Control and Prevention, the Saudi Ministry of Health, and the Saudi Center for Disease Prevention and Control $[10,26,27]$. The questionnaire comprised five sections: demographic data, general COVID-19 knowledge, prevention practices knowledge, home quarantine knowledge, and knowledge of governmental measures to stop the spread of COVID-19. Questions were prepared and arranged according to pretested available questionnaires designed to assess public knowledge and awareness of infectious diseases [28]. Furthermore, except for the high-risk group question, which had four choices with one most appropriate answer, all the other questions had three options: as "Yes", "No", and "I do not know". The most appropriate answers were considered the correct responses and scored "one", while inappropriate answers and "I do not know" answers were considered incorrect responses and scored "zero". The reliability of the questionnaire's sections was evaluated by conducting a pilot study on 87 participants. Cronbach's alpha coefficients were as follows: general knowledge $=0.82$, prevention knowledge $=0.76$, home quarantine knowledge $=0.69$ and governmental restrictions knowledge $=0.76$ ). Similarly, the scientific credibility and validity of the tool was evaluated by three independent public health preventive medicine experts, who provided feedback on the accuracy, relevance, and simplicity of the included questions and statements with reference to the 
knowledge sources used to create the questionnaire, which resulted in the improved clarity and presentation of all items.

\section{Statistical analysis}

Three levels of knowledge were established: excellent, intermediate, and poor.

Moreover, the scores were classified in three close intervals as follows: two-thirds and more correct responses was considered "excellent", one-third to less than two-thirds correct responses "intermediate," and one-third and less correct responses "poor" [29].

Demographic variables were analysed using the frequency distribution for categorical variables. The chisquare test was used to test the differences in knowledge levels by selected independent demographic variables for categorical and proportion data. The statistical significance level was set at a P-value < 0.05. All analyses were performed using the statistical software package STATA (StataCorp. 2017. Stata Statistical Software: Release 15. College Station, TX).

\section{Results}

The total cohort consisted of 1006 participants after we excluded healthcare workers, who might have introduced bias due to the main study objective, i.e., to test the knowledge of the general public. There were no missing data, as the questionnaire was designed to capture complete responses to all questions. Data were collected after the WHO declared COVID-19 as a pandemic and a threat to the world's public health [12]. During the period of data collection, the number of confirmed positive COVID-19 cases in Saudi Arabia ranged from 500 to 1200, with four reported cases of death [23]. Participants were categorized according to their gender, nationality, age group, and level of education. Male participants accounted for $61.7 \%$ of the total sample, and the 21-30 and 31-40-year-old age groups were the largest two segments, representing $34.3 \%$ and $29.1 \%$ of the participants, respectively. Moreover, Saudi nationals accounted for $92.3 \%$ of participants, and participants with a college or university degree accounted for $72.4 \%$ of the total respondents (Table 1 ).

General knowledge of COVID-19 was assessed by 14 questions on high-risk groups, transmission, availability of a vaccine and treatment, signs and symptoms, and possible complications (Table 2). Regarding overall knowledge of COVID-19, $75 \%, 24 \%$ and $1 \%$ of the participants had excellent, intermediate, and poor knowledge levels, respectively.

Specifically, the differences in the reported levels of knowledge by gender and level of education were not statistically significant. In contrast, we found that older participants were significantly more likely to have excellent knowledge levels than younger participants (P-value of 0.008$)$. Moreover, Saudi nationals had significantly higher levels of knowledge than non-Saudi nationals (P-value of 0.027 ). 
Knowledge of COVID-19 prevention practices, such as the avoidance of crowded places and close contact with people who had tested positive, correct practices for coughing and sneezing, social distancing, cleaning and disinfection of surfaces, and stay at home measures, was measured through another set of questions and statements (Table 3 ). Most participants ( $98.4 \%$ of all respondents) reported an excellent level of knowledge of COVID- 19 prevention practices regardless of their demographic characteristics. There were no statistically significant differences across categories. Table 3 presents the percentages of participants with different levels of prevention knowledge by demographic characteristic.

Participants were asked questions related to what they should do if they were in home quarantine due to a definite or suspected case of COVID-19, and $75.8 \%$ and $22.5 \%$ of participants reported excellent and intermediate knowledge, respectively. Participants in the older age groups reported higher knowledge of home quarantine knowledge and compliance, as the age groups of 51-60 years old and more than 60 years old were the two age groups with the highest percentages of excellent responses $(86.6 \%$ and $86.4 \%$, respectively) (P-value of 0.001) (Table 4).

As the government of Saudi Arabia took extreme measures to control and stop the spread of COVID-19, participants' knowledge of measures required by the government was assessed. Table 5 shows the set of questions related to the government measures to stop the spread of COVID-19. In total, $53.7 \%, 45.8 \%$, and $0.5 \%$ of participants reported excellent, intermediate, and poor knowledge, respectively. Although most participants from most demographic categories reported similar responses, there were significant differences by nationality and level of education in responses related to the government measures to stop the spread of COVID-19 (P-values of 0.009 and 0.001 , respectively). In addition to the four main sections of questions on COVID-19 knowledge, participants were asked one general question about when they expected the COVID-19 pandemic to be controlled. The majority (43.8\%) expected the pandemic to be over within a few months, while $22.9 \%$ and $7.6 \%$ expected the crisis to be resolved within weeks or after more than a year, respectively; $25.7 \%$ said they do not know when such a crisis would be over.

\section{Discussion}

Awareness of $\mathrm{CoV}$ in general has always been common in Saudi Arabia, as the Kingdom has experienced various outbreaks of MERS-CoV, starting in 2012 [5], and still recorded limited cases and clusters of the infection as of the latest WHO report on April 8th 2020 [30]. This study assessed knowledge of the general public regarding the 2019 novel coronavirus during the early stages of the spread of COVID-19 in Saudi Arabia in March 2020. The findings of this research can be helpful in designing and implementing prevention and public compliance programmes for COVID-19 by the Saudi Ministry of Health and nonhealth-related entities. Specifically, the outcomes of this study address various levels of knowledge of COVID-19 in general, prevention, home quarantine compliance, and governmental measures aimed at stopping the spread of COVID-19.

Three-quarters of our sample demonstrated excellent knowledge of COVID-19, which can be explained by the high intensity of media coverage in Saudi Arabia and the close attention of health officials, who have 
conducted daily press briefings highlighting the current COVID-19 situation in the Kingdom. Our study shows similar outcomes to a study conducted to assess the general public awareness of MERS-CoV conducted by Al-Mohrej et al. [31] Although our study classifies levels of knowledge as excellent, intermediate, or poor, Al- Mohrej et al. [31] took another approach by assessing proportions of the most appropriate answers, which might limit the overall understanding of various levels of awareness and knowledge.

Currently, there are no specific vaccines or treatments for COVID-19. However, scientists from all over the world are evaluating potential treatments, as evidenced by the many ongoing clinical trials. Consequently, focusing on strategic prevention measures by educating the public about the disease caused by the virus and how the virus spreads seems to be an important proactive measure. The majority of participants in our study showed an excellent level of knowledge of prevention practices. The fact that there are no available vaccines and treatments should enhance people's compliance with prevention measures such as social distancing and personal hygiene practices.

Excellent knowledge of prevention was reported by approximately $95 \%$ of participants in this study. These results on knowledge of prevention practices demonstrate two findings. First, an excellent level of knowledge was the dominant outcome. Second, there were no significant differences among the demographic groups, which illustrates consistency in practices related to COVID-19 prevention measures and practices by the general public. In contrast to our findings, an online survey of respondents in the United States and the United Kingdom showed inappropriate conceptions of COVID-19 transmission and prevention among participants that was mainly caused by false social media content [32]. Furthermore, high knowledge levels of COVID-19 prevention might help limit the spread of the virus as the world, including Saudi Arabia, races to control COVID-19 by working on potential vaccines and treatments. Meanwhile, high levels of prevention knowledge should be sustained with more and frequent simplified guiding information and tools, which will help minimize the spread of COVID-19 by increasing individuals' knowledge until an effective vaccine and treatment become available.

The questions related to knowledge of home quarantine were constructed based on the latest WHO recommendations for persons who have been exposed to people who tested positive for COVID-19 [33]. Compliance with home quarantine relies on good knowledge of its requirements. In addition, our findings showed acceptable levels of home quarantine knowledge considering that home quarantine was an uncommon practice in Saudi Arabia until COVID-19 became a global pandemic. More specifically, older participants reported higher levels of knowledge than younger participants less than 30 years old. This finding emphasizes the need to focus on young people using relevant content and platforms, which will enhance their knowledge and compliance with COVID-19 home quarantine requirements.

Reported knowledge of the measures required by the government to prevent the spread of COVID-19 was the lowest among all types of knowledge in this study. Overall, approximately $50 \%$ of participants reported excellent knowledge, and we observed differences in knowledge levels by nationality and level of education. Additionally, the study illustrates that high levels of knowledge of the disease and its 
prevention measures might not be enough to support compliance with the imposed restrictions by the government, such as complete or partial lockdowns. In addition, non-Saudi nationals reported knowledge levels of governmental measures that were clearly below those reported by Saudi nationals, which is consistent with the higher rates of infection among non-Saudi nationals [34].

\section{Conclusion}

Knowledge of COVID-19 in general was excellent, including knowledge of prevention practices and home quarantine measures. However, knowledge of governmental restrictions to stop the spread of COVID-19 was excellent only among half of the participants. The study recommends that ongoing updates on COVID-19 information, directions, and prevention measures continue to be provided with enhanced clarity and emphasis of messages related to governmental restrictions to control COVID-19.

\section{Limitations of the study}

This study has various limitations, such as a lack of other comparable studies, as the topic is still evolving. Consequently, this limitation was addressed through the comparison of our outcomes with the results of studies related to SARS-CoV or MERS-CoV instead.

Furthermore, some answers to the questions included in the study tool might have been easily guessed, and a future study that includes distracting answers might be helpful in determining levels of COVID-19 knowledge. Moreover, data collection for this study was carried out through the random circulation of the questionnaire on social media covering a random sample of people in Saudi Arabia, which did not ensure equal representation across all demographic variables and regions. Although the sampling procedure and the results do not present a nation-wide outcome, researchers might find this study useful when conducting studies of the same or a similar concept in a nationally representative sample. Finally, the outcomes of this study might be relevant only to Saudi Arabia due to differences in the circulation of COVID-19 information in other countries. For instance, populations in Saudi Arabia rely heavily on social media as a source of information, which might not be the case in other locations.

\section{Abbreviations}

CoVs: coronaviruses; COVID-19: coronavirus disease 2019; OC43: beta coronavirus; 229E: alpha coronavirus; NL63: alpha coronavirus; HKU: beta coronavirus; SARS: severe acute respiratory syndrome; SARS-CoV-2: severe acute respiratory syndrome coronavirus 2; MERS: Middle East respiratory syndrome; WHO: World Health Organization

\section{Declarations}

\section{Acknowledgements}


The authors would like to thank all colleagues and persons who posted and helped circulate the study questionnaire on their social media profiles and the participants who contributed their responses to this study.

\section{Funding}

No funding was used to assist in the preparation of this study.

\section{Availability of data and materials}

The datasets used and/or analysed in the current study are available from the corresponding author on reasonable request.

\section{Authors' contributions}

$\mathrm{MH}$ and $\mathrm{AA}$ designed the study and the questionnaire. MA and $\mathrm{AA}$ carried out the data collection. $\mathrm{MH}$ analysed and interpreted the data. $\mathrm{MH}, \mathrm{AA}$, and VK drafted the manuscript. All authors approved the final version of the manuscript.

\section{Ethics approval and consent to participate}

The study was reviewed and approved by the research ethics committee at King Khaled University in Abha, Saudi Arabia (Reference ECM\# 2020-2018 - HAPO-06-01). Prior to participation, respondents were asked to take part in the study voluntarily and to not provide personal or identity-revealing information to maintain anonymity and confidentiality. A statement was included in the questionnaire explaining the purpose of the study. Participants' completion of the questionnaire was considered consent to participate in the study.

\section{Consent for publication}

Not applicable

\section{Competing interests}

All authors declare that they have no competing interests.

\section{Authors' details}


1Department of Pharmacology, College of Pharmacy, King Khalid University, Guraiger, Abha, Saudi Arabia. 2Medical Services Company by AbbVie Biopharmaceutical, Jeddah, Saudi Arabia. 3Faculty of Health and Life Sciences, De Montfort University, Leicester, United Kingdom. 4Palladium: Make It Possible, Riyadh, Saudi Arabia

\section{References}

1. Hamre D, Procknow JJ. A new virus isolated from the human respiratory tract. Proc Soc Exp Biol Med. 1966;121:190-3.

2. Mclntosh K, Dees JH, Becker WB, Kapikian AZ, Chanock RM. Recovery in tracheal organ cultures of novel viruses from patients with respiratory disease. Proc Natl Acad Sci U S A. 1967;57:933-40.

3. van der Hoek L, Pyrc K, Jebbink MF, Vermeulen-Oost W, Berkhout RJ, Wolthers KC, et al. Identification of a new human coronavirus. Nat Med. 2004;10:368-73.

4. Woo PC, Lau SK, Chu CM, Chan KH, Tsoi HW, Huang Y, et al. Characterization and complete genome sequence of a novel coronavirus, coronavirus HKU1, from patients with pneumonia. J Virol. 2005;79:884-95.

5. Zaki AM, van Boheemen S, Bestebroer TM, Osterhaus AD, Fouchier RA. Isolation of a novel coronavirus from a man with pneumonia in Saudi Arabia. N Engl J Med. 2012;367:1814-20.

6. Drosten C, Günther S, Preiser W, van der Werf S, Brodt HR, Becker S, et al.Identification of a novel coronavirus in patients with severe acute respiratory syndrome. N Engl J Med. 2003;348:1967-76.

7. Huang C, Wang Y, Li X, Ren L, Zhao J, Hu Y, et al. Clinical features of patients infected with 2019 novel coronavirus in Wuhan, China. Lancet. 2020;395:497-506.

8. Cheng VC, Lau SK, Woo PC, Yuen KY. Severe acute respiratory syndrome coronavirus as an agent of emerging and reemerging infection. Clin Microbiol Rev. 2007;20:660-94.

9. World Health Organization. Middle east respiratory syndrome coronavirus (MERS- CoV) - Saudi Arabia. 2020. https://www.who.int/csr/don/09-october-2017-mers- saudi-arabia/en/. Accessed 15 Mar

10. Centers for Disease Control and Prevention. Coronavirus disease 2019 (COVID19). https://www.cdc.gov/coronavirus/2019-ncov/index.html. Accessed 17 Apr 2020.

11. World Health Organization. Naming the coronavirus disease (COVID-19) and the virus that causes it. 2020. https://www.who.int/emergencies/diseases/novel- coronavirus-2019/technicalguidance/naming-the-coronavirus-disease-(covid-2019)- and-the-virus-that-causes-it. Accessed 17 Apr

12. World Health Organization. WHO director-general's opening remarks at the media briefing on COVID19 - 11 March 2020. 2020. https://www.who.int/dg/speeches/detail/who-director-general-s-openingremarks-at- the-media-briefing-on-covid-19 11-march-2020. Accessed $16 \mathrm{Mar}$ 
13. World Health Organization. Report of the WHO-China joint mission on coronavirus disease 2019 (COVID-19). 2020. https://www.who.int/publications-detail/report-of- the-who-china-joint-mission-oncoronavirus-disease-2019-(covid-19). Accessed 17 Apr

14. Rothe C, Schunk M, Sothmann P, Bretzel G, Froeschl G, Wallrauch C, et al.Transmission of 2019-nCoV infection from an asymptomatic contact in Germany. N Engl J Med. 2020;382:970-1.

15. Li Q, Guan X, Wu P, Wang X, Zhou L, Tong Y, et al. Early transmission dynamics in Wuhan, China, of novel coronavirus-infected pneumonia. N Engl J Med. 2020;382:1199-207.

16. Guan WJ, Ni ZY, Hu Y, Liang WH, Ou CQ, He JX, et al. Clinical characteristics of coronavirus disease 2019 in China. N Engl J Med. 2020; doi:10.1056/NEJMoa2002032.

17. Lauer SA, Grantz KH, Bi Q, Jones FK, Zheng Q, Meredith HR, et al. The incubation period of coronavirus disease 2019 (COVID-19) from publicly reported confirmed cases: estimation and application. Ann Intern Med. 2020; doi:10.7326/m20-0504.

18. Grasselli G, Pesenti A, Cecconi M. Critical care utilization for the COVID-19 outbreak in Lombardy, Italy: early experience and forecast during an emergency response. JAMA. 2020; doi:10.1001/jama.2020.4031.

19. Onder G, Rezza G, Brusaferro S. Case-fatality rate and characteristics of patients dying in relation to COVID-19 in Italy. JAMA. 2020; doi:10.1001/jama.2020.4683.

20. Chen N, Zhou M, Dong X, Qu J, Gong F, Han Y, et al. Epidemiological and clinical characteristics of 99 cases of 2019 novel coronavirus pneumonia in Wuhan, China: a descriptive study. Lancet. 2020;395:507-13.

21. Wang D, Hu B, Hu C, Zhu F, Liu X, Zhang J, et al. Clinical characteristics of 138 hospitalized patients With 2019 novel coronavirus-infected pneumonia in Wuhan, China. JAMA. 2020; doi:10.1001/jama.2020.1585.

22. Ministry of Health. $\mathrm{MOH}$ news $-\mathrm{MOH}$ reports first case of coronavirus (2020) https://www.moh.gov.sa/en/Ministry/MediaCenter/News/Pages/News-2020-03- 02002.aspx. Accessed cited 17 Mar 2020.

23. Covid19 Ministry of Heath. COVID-19 dashboard: Saudi Arabia. 2020. https://covid19.moh.gov.sa/. Accessed 17 Apr

24. Sample size calculator by raosoft, Inc. 2020. http://www.raosoft.com/samplesize.html. Accessed 18 Mar 2020.

25. General Authority for Statistics. Population estimates. 2020. https://www.stats.gov.sa/en/43. Accessed 17 Apr

26. Ministry of Health. Public health - novel coronavirus (COVID-19). 2020. https://www.moh.gov.sa/en/HealthAwareness/EducationalContent/PublicHealth/Page s/corona.aspx. Accessed 17 Mar

27. Community \& public. 2020. https://covid19.cdc.gov.sa/community-public/. Accessed 17 Mar 2020. 
28. Liu H, Li M, Jin M, Jing F, Wang H, Chen K. Public awareness of three major infectious diseases in rural Zhejiang province, China: a cross-sectional study. BMC Infectious Diseases. 2013;13(1).

29. Nooh H, Alshammary R, Alenezy J, Alrowaili N, Alsharari A, Alenzi N et al. Public awareness of coronavirus in Al-Jouf region, Saudi Arabia. Journal of Public Health. 2020;13,:1-8

30. World Health Organization. Middle East respiratory syndrome coronavirus (MERS- CoV) - The Kingdom of Saudi Arabia. 2020. https://www.who.int/csr/don/08-april-2020-mers-saudi-arabia/en/. Accessed 18 Apr

31. Al-Mohrej OA, Al-Shirian SD, Al-Otaibi SK, Tamim HM, Masuadi EM, Fakhoury HM. Is the Saudi public aware of Middle East respiratory syndrome? J Infect Public Health. 2016;9:259-66.

32. Geldsetzer P. Knowledge and perceptions of COVID-19 among the general public in the United States and the United Kingdom: a cross-sectional online survey. Ann Intern Med. 2020; doi:10.7326/m200912.

33. The World Health Organization. Guidelines for home quarantine. 2020.

https://www.who.int/docs/default-source/searo/whe/coronavirus19/the-guideline-for- homequarantine--quarantine-in-non-health-care-settings-is-intended-for-anyone- who-believes-they-havebeen-exposed-to-covid-19-and-are-required-to-be-home- quarantined-to-prevent-community-trans.pdf? sfvrsn=1bc12565_4. Accessed 18 Mar 2020.

34. Saudi Press Agency. New Cases Detected via Active Screening. 2020. https://www.spa.gov.sa/viewstory.php?lang=en\&newsid=2076884. Accessed 20 Apr 2020.

\section{Tables}

Table 1 Demographic characteristics

\begin{tabular}{lll}
\hline Variable & Number $(\mathrm{n})$ & Percentage (\%) \\
\hline $\begin{array}{l}\text { Gender } \\
\text { Male }\end{array}$ & 621 & \\
$\quad$ Female & 385 & 61.7 \\
\hline Nationality & & 38.3 \\
$\quad$ Saudi & 928 & 92.3 \\
$\quad$ Non-Saudi & 78 & 7.7 \\
Age Group (years) & & \\
\hline 15-20 & 109 & 10.8 \\
\hline 21-30 & 345 & 34.3 \\
\hline $1-40$ & 293 & 29.1 \\
\hline 41-50 & 170 & 16.9 \\
\hline 51-60 & 67 & 6.7 \\
\hline Ed & 22 & 2.2 \\
\hline Secondion & & \\
\hline College or university level & 728 & 27.6 \\
\hline
\end{tabular}


Table 2 General knowledge of COVID-19

Intermediate Excellent

P-value

1. High-risk groups

2. Is the new coronavirus like the common flu?

3. Does receiving a letter or package from an infected country put you at risk of being infected with the new coronavirus?

4. Is there currently a vaccine available that protects against infection with the new coronavirus?

5. Is there a treatment for the new coronavirus?

6. Older adults and people of any age who have serious underlying medical conditions may be at higher risk for more serious complications from the new coronavirus.

7. Coronavirus can be transmitted when you touch contaminated surfaces with droplets from an infected person and touch your eyes, mouth, or face afterward.

8. It is also possible for the coronavirus to be transmitted through diffused droplets in the air from those infected.

9. Signs and Symptoms: Fever

10. Signs and Symptoms: Cough

11. Signs and Symptoms: Shortness of Breath

12. Complications: Pneumonia

13. Complications: Multi Organ Failure

14. Complications: Death

$\mathrm{n}(\%) \quad \mathrm{n}(\%) \quad \mathrm{n}(\%)$

\begin{tabular}{|c|c|c|c|c|}
\hline & & & & \\
\hline Gender & & & & 0.554 \\
\hline Male & $5(0.8)$ & $144(23.2)$ & $472(76)$ & \\
\hline Female & $5(1.3)$ & $97(25.2)$ & $283(73.5)$ & \\
\hline Nationality & & & & 0.027 \\
\hline Saudi & $7(0.8)$ & $221(23.8)$ & $700(75.4)$ & \\
\hline Non-Saudi & $3(3.9)$ & $20(25.6)$ & $55(70.5)$ & \\
\hline $\begin{array}{l}\text { Age Group } \\
\text { (vears) }\end{array}$ & & & & 0.008 \\
\hline $\begin{array}{l}\text { (years) } \\
15-20\end{array}$ & $2(18)$ & $43(395)$ & $64(5877)$ & \\
\hline $21-30$ & $4(1.2)$ & $89(25.8)$ & $252(73)$ & \\
\hline $31-40$ & $2(0.7)$ & 53 (18.1) & $238(81.2)$ & \\
\hline $41-50$ & $1(0.6)$ & $38(22.4)$ & $131(77)$ & \\
\hline $51-60$ & $1(1.5)$ & $14(20.9)$ & $52(77.6)$ & \\
\hline$>61$ & $0(0)$ & $4(18.2)$ & $18(81.8)$ & \\
\hline Education & & & & 0.202 \\
\hline Secondary & $5(1.8)$ & $71(25.5)$ & $202(72.7)$ & \\
\hline $\begin{array}{l}\text { school or less } \\
\text { College or } \\
\text { university level }\end{array}$ & $5(0.7)$ & $170(23.4)$ & $553(75.9)$ & \\
\hline
\end{tabular}

Table 3: Knowledge of CIVUD 19 prevention practices 


\begin{tabular}{|c|c|c|c|c|c|}
\hline $\begin{array}{l}\text { Prevention Practices } \\
\text { Statements }\end{array}$ & Variable & $\begin{array}{l}\text { Poor } \\
\text { n } \\
(\%)\end{array}$ & $\begin{array}{l}\text { Intermediate } \\
\mathrm{n}(\%)\end{array}$ & $\begin{array}{l}\text { Excellent } \\
\mathrm{n}(\%)\end{array}$ & $\begin{array}{l}\mathrm{P}- \\
\text { value }\end{array}$ \\
\hline 1. Avoid crowded places & Gender & & & & 0.513 \\
\hline $\begin{array}{l}\text { 2. Avoid close contact } \\
\text { with people who are sick }\end{array}$ & Male & $\begin{array}{l}1 \\
(0.2)\end{array}$ & $9(1.4)$ & $611(98.4)$ & \\
\hline $\begin{array}{l}\text { 3. Cover your cough or } \\
\text { sneeze with a tissue and } \\
\text { then throw the }\end{array}$ & Female & $\begin{array}{l}2 \\
(0.5)\end{array}$ & $4(1)$ & $379(98.5)$ & \\
\hline $\begin{array}{l}\text { tissue in the trash } \\
\text { 4. Avoid touching your } \\
\text { eyes, nose, and mouth }\end{array}$ & $\begin{array}{l}\text { Nationality } \\
\text { Saudi }\end{array}$ & $\begin{array}{l}2 \\
(0.2)\end{array}$ & $12(1.3)$ & $\begin{array}{l}914 \\
(98.5)\end{array}$ & 0.252 \\
\hline $\begin{array}{l}\text { 5. Clean and disinfect } \\
\text { frequently touched } \\
\text { objects and surfaces }\end{array}$ & Non-Saudi & $\begin{array}{l}1 \\
(1.3)\end{array}$ & $1(1.3)$ & $76(97.4)$ & \\
\hline $\begin{array}{l}\text { 6. Wash your hands } \\
\text { often with soap and } \\
\text { water for at least } 40\end{array}$ & Age Group (years) & & & & 0.100 \\
\hline seconds & $15-20$ & $\begin{array}{l}1 \\
(0.9)\end{array}$ & $4(3.7)$ & $\begin{array}{l}104 \\
(95.4)\end{array}$ & \\
\hline $\begin{array}{l}\text { 7. Avoid sharing your } \\
\text { mobile phone and } \\
\text { personal belongings }\end{array}$ & $21-30$ & $0(0)$ & $3(0.9)$ & $\begin{array}{l}342 \\
(99.1)\end{array}$ & \\
\hline $\begin{array}{l}\text { 8. Maintain an } \\
\text { appropriate distance } \\
\text { from gathering areas, as } \\
\text { the }\end{array}$ & $31-40$ & $0(0)$ & $3(1)$ & $290(99)$ & \\
\hline $\begin{array}{l}\text { virus is transmitted by } \\
\text { saliva droplets at a } \\
\text { distance of up to one }\end{array}$ & $41-50$ & $\begin{array}{l}2 \\
(1.2)\end{array}$ & $1(0.6)$ & $\begin{array}{l}167 \\
(98.2)\end{array}$ & \\
\hline to two metres & $51-60$ & $0(0)$ & $1(1.5)$ & $66(98.5)$ & \\
\hline $\begin{array}{l}\text { 9. Stay home when you } \\
\text { are sick, except to get } \\
\text { medical care }\end{array}$ & $>61$ & $0(0)$ & $1(4.6)$ & $21(95.4)$ & \\
\hline $\begin{array}{l}\text { 10. Stay home if } \\
\text { instructed by } \\
\text { government agencies } \\
\text { and health }\end{array}$ & Education & & & & 0.101 \\
\hline \multirow[t]{2}{*}{$\begin{array}{l}\text { officials even if you ar } \\
\text { less }\end{array}$} & $\begin{array}{l}\text { not sick } \\
\text { Secondary school or }\end{array}$ & $\begin{array}{l}1 \\
(0.4)\end{array}$ & $7(2.5)$ & $270(97.1)$ & \\
\hline & College or university level & $\begin{array}{l}2 \\
(0.3)\end{array}$ & $6(0.8)$ & $720(98.9)$ & \\
\hline
\end{tabular}


Table 4 Knowledge of home quarantine measures for exposed, suspected, or positive cases of COVID-19

Home Quarantine Variable Poor Intermediate Excellent P-

Measures

$\mathrm{n} \quad \mathrm{n}(\%) \quad \mathrm{n}(\%)$

$(\%)$

1. Stay home, Gender

except going out

for medical treatment

Male

$10 \quad 128(20.6) \quad 483$

2. Use separate toilets

1. Wash hand frequently for 40 seconds

(1.6)

Female

Nationality

Saudi

. Monitor

symptoms and

call 937 if

they get worse

5. Maintain good Age Group (years)

Non-Saudi

$98(25.5)$

(77.8)

280

(72.7) value

0.188 ventilation

6. Isolate yourself from others in the same home by staying inside the room

7. Do not share home equipment and personal belongings $15-20$

8. Wear a face mask if you need to go out

21-30

6

(1.7)

4

(1.4)

41-50

$51-60$

$>61$

Education

Secondary school or less

College or university level

3

(1.8)

1

(1.5)
$16 \quad 209(22.5) \quad 703$

(1.7)

(75.8) 1 $226(21.8) \quad 60(76.9)$ (1.3)

$\begin{array}{lll}3 & 36(33) & 70(64.2) \\ (2.8) & \end{array}$

$0(0) \quad 3(13.6)$

8 (11.9)

$28(16.5)$

139

58 (86.6)

237

(80.9)

0.945

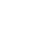




\begin{tabular}{|c|c|c|c|c|c|}
\hline $\begin{array}{l}\text { Governmental Measures to } \\
\text { Prevent the Spread } \\
\text { of COVID-19 }\end{array}$ & Variable & $\begin{array}{l}\text { Poor } \\
\text { n } \\
(\%)\end{array}$ & $\begin{array}{l}\text { Intermediate } \\
\mathrm{n}(\%)\end{array}$ & $\begin{array}{l}\text { Excellent } \\
\mathrm{n}(\%)\end{array}$ & $\begin{array}{l}\mathrm{P}- \\
\text { value }\end{array}$ \\
\hline 1. Quarantine everyone & Gender & & & & 0.133 \\
\hline $\begin{array}{l}\text { coming in from } \\
\text { abroad for } 14 \text { days }\end{array}$ & Male & $\begin{array}{l}3 \\
(0.5)\end{array}$ & $300(48.3)$ & $\begin{array}{l}318 \\
(51.2)\end{array}$ & \\
\hline 2. Suspend all air travel & Female & $\begin{array}{l}2 \\
(0.5)\end{array}$ & $161(41.8)$ & $\begin{array}{l}222 \\
(57.7)\end{array}$ & \\
\hline $\begin{array}{l}\text { 3. Go door to door to } \\
\text { measure everyone's }\end{array}$ & Nationality & & & & 0.009 \\
\hline temperature & Saudi & $\begin{array}{l}3 \\
(0.3)\end{array}$ & $420(45.3)$ & $\begin{array}{l}505 \\
(54.4)\end{array}$ & \\
\hline $\begin{array}{l}\text { 4. Close all schools and } \\
\text { universities }\end{array}$ & Non-Saudi & $\begin{array}{l}2 \\
(2.5)\end{array}$ & $41(52.6)$ & $35(44.9)$ & \\
\hline $\begin{array}{l}\text { 5. Forbid any mass } \\
\text { gatherings (e.g., sport }\end{array}$ & Age Group (years) & & & & 0.060 \\
\hline events or concerts) & $15-20$ & $\begin{array}{l}2 \\
(1.8)\end{array}$ & $57(52.3)$ & $50(45.9)$ & \\
\hline $\begin{array}{l}\text { 6. Make it mandatory for } \\
\text { adults to wear a face }\end{array}$ & $21-30$ & $0(0)$ & $158(45.8)$ & $\begin{array}{l}187 \\
(54.2)\end{array}$ & \\
\hline mask while outdoors & $31-40$ & $0(0)$ & $136(46.4)$ & $\begin{array}{l}157 \\
(53.6)\end{array}$ & \\
\hline $\begin{array}{l}\text { 7. Require everyone to } \\
\text { remain in their homes }\end{array}$ & $41-50$ & $\begin{array}{l}3 \\
(1.8)\end{array}$ & $71(41.8)$ & $96(56.4)$ & \\
\hline \multirow[t]{4}{*}{$\begin{array}{l}\text { except to seek medical } \\
\text { care }\end{array}$} & $51-60$ & $0(0)$ & $27(40.3)$ & $40(59.7)$ & \\
\hline & $>61$ & $0(0)$ & $12(54.5)$ & $10(45.5)$ & \\
\hline & $\begin{array}{l}\text { Education } \\
\text { Secondary } \\
\text { school or less }\end{array}$ & $\begin{array}{l}2 \\
(0.7)\end{array}$ & $153(55)$ & $\begin{array}{l}123 \\
(44.3)\end{array}$ & 0.001 \\
\hline & $\begin{array}{l}\text { College or } \\
\text { university level }\end{array}$ & $\begin{array}{l}3 \\
(0.4)\end{array}$ & $308(42.3)$ & $\begin{array}{l}417 \\
(57.3)\end{array}$ & \\
\hline
\end{tabular}

